\title{
Analyzing the determinant variables on the difficulty of transfer power of rural and urban property tax from central to regional government in Indonesia
}

\author{
Haula Rosdiana ${ }^{1, *}$, Edi Slamet Irianto ${ }^{2}$, and Murwendah ${ }^{1}$ \\ ${ }^{1}$ Department of Tax Administration Science, Faculty of Administrative Science, Universitas \\ Indonesia, Indonesia \\ ${ }^{2}$ Directorate General of Taxation, Ministry of Finance of Republic of Indonesia, Indonesia
}

\begin{abstract}
Motivated by rapid development of local autonomy and fiscal decentralization in Indonesia, this study aims to analyze determinant variables that causing the difficulty in the transfer policy of Rural and Urban Property Tax from central to regional governments. This program was designed to mitigate the fiscal disparities and revenue inequality among local authorities, also to increase the local people welfare. To comply with Government Law Number 28/2010 on Regional Tax and Levy, government transfers the right and authority of Rural and Urban Property Tax from central into regional government since 1 January 2011. By 31 December 2012, only 18 regional authorities have undergone the program and the rest seems to be having some difficulties. The study adopted a constructivism approach with qualitative method. The results show some determinant variables that causing the difficulties on this policy: (1) the weakness of bureaucratic attitude adhering to local government; (2) central and regional government are still not on the same page on collecting fee for Rural and Urban Property Tax; (3) the unclear formulation on fee collection of Rural and Urban Property Tax; (4) the lack of competency in the local government and short of experiences in Rural and Urban Property Tax collection.
\end{abstract}

\section{Introduction}

The implementation of local autonomy and fiscal decentralization has been playing an important role for the development and advancement of local the governments in Indonesia. The longer regional autonomy runs, the larger the authority of local government in selfregulation. Any decision makings for the strategic fiscal areas particularly in the formulation of taxes and spending are now fully authorized in the local government without any interference of the central government. The fundamental spirits of this fiscal decentralization are mainly for mitigating fiscal disparities and balancing revenue inequality among local authorities as well as for increasing the local people welfare. It is

\footnotetext{
* Corresponding author: h.rosdiana@ui.ac.id
} 
aligned with one of the goals of Sustainable Development Goals which is eradicating the poverty. This fiscal decentralization policy could increase fiscal capacity of local authorities in combating poverty in local level.

An innovation program to support this agenda is the transfer policy of Rural and Urban Property Tax from central into local government under the implementation of Government Law 28 of 2009 on Regional Tax and Levy. This program is principally underlined with several frameworks: (a) the right and authority of Rural and Urban Property Tax is shifted from central into local government; (b) self-regulation in Rural and Urban Property Tax rates for local government; (c) regional authority has the power to design tax exemption; (d) local authority has the right to govern the administrative system for collecting Rural and Urban Property Tax. Although the execution of Government Law 28 of 2009 has significantly enlarged the power of local authority on Rural and Urban Property Tax, however the strength of local government in self-regulation should totally comply with this Government Law 28 of 2009.

Unfortunately, this policy does not seem to run smoothly. A year after the policy running or until the end of 2011, there is only one local authority which has performed this programm which is Surabaya, as a pioneer. In 2012, there is a slightly improvement when 12 regional authorities followed what undertaken by Surabaya. In this regard, over the last two years of implementation or until 31 December 2012, there are 18 regional authorities $(3,66 \%)$ of total 492 local governments which have accomplished this program and the rest seems to be having obstacles and still not yet begun.

In addition, statistics of Minister of Finance enlighten that until March 2013, there are 284 local authorities $(57,72 \%)$ that has formulated the associated regulations on Rural and Urban Property Tax, meanwhile a number of 107 local governments $(21,75 \%)$ are on the state of formulation process. Unfortunately, the rest of 101 regional authorities $(20,53 \%)$ in the condition of uncertainty and they have not yet prepared any rules on Rural and Urban Property Tax as shown in the Table 1 [9].

Table 1. State of Readiness of Local Government for Regulations.

\begin{tabular}{|c|c|c|}
\hline State of Readiness & $\begin{array}{c}\text { Total of } \\
\text { Local } \\
\text { Authorities }\end{array}$ & $\begin{array}{c}\text { In } \\
\text { Percentage }\end{array}$ \\
\hline Well-prepare of regulations & 284 & $57.72 \%$ \\
\hline Collection in 2011 & 1 & $0.20 \%$ \\
\hline Collection in 2012 & 17 & $3.46 \%$ \\
\hline Collection in 2013 & 105 & $21.34 \%$ \\
\hline Collection in 2014 & 161 & $32.72 \%$ \\
\hline In the formulation process & 107 & $21.75 \%$ \\
\hline Unprepared positions & 101 & $20.53 \%$ \\
\hline Total & 492 & $100.00 \%$ \\
\hline
\end{tabular}

The existence of the great number of local authorities with the unwell-prepared status reflects that the running of this program requires some terms and conditions as prerequisites. To do this policy properly and timely, local government needs a series of organized preparation with a systematic process. In addition, the application of the program 
requires basic standards regarding competency and experiences for human resources who will be working in this area. It also needs a set of instrument such as offices, supplies, equipment, technologies and others to help working in this area.

The huge requirements in this project are costly for several local authorities, particularly for regional government with non-sufficient budget or poor state. Consequently, several local authorities appear to be reluctant to carry out this program because they assume that it will only increase the burden as well as enlarge the budget deficit. Furthermore, some heads of regional authorities view this project is as not an advantageous project due to the need for capital expenditures and investments seem to be higher than the potential revenue from this area. This uneasy condition yields a hesitation and uncertainty among the authorities that the program might not be effective.

In order to measure whether this devolution program is effective or not, it has been examined in the trend of realization of Rural and Urban Property Tax revenue in 2011 and 2012 for 18 local authorities which have completely conducted this policy. As a result, 16 local authorities $(88,89 \%)$ increased their revenues with the highest annual growth went to Deli Serdang and Medan for each annual growth about 40,23\% and 38,74\%. Meanwhile, Surabaya as a pioneer of this project has reached annual growth around $14,54 \%$. On the contrary, Pontianak and Gorontalo reached negative annual growth, each 3,89\% and 7,39\%. In 2011, the realization of Rural and Urban Property Tax revenue of Pontianak is IDR 15,36 billion and slightly decreased into IDR 14,77 billion in 2012 as well as Gorontalo from IDR 3,89 billion in 2011 became IDR 3,60 billion in 2012. With this regard, we conclude that this program is helpful and beneficial for majority of local authorities therefore this policy is sufficient, effective and, having a continuity is a necessary.

\section{Theoretical Framework}

The transfer policy of Rural and Urban Property Tax from central into local government should not only be viewed as a sort of fiscal decentralization but also as a form of political devolution reflecting a strategic innovation that performed by the central government to enhance the running of democracy in local the government as well as to bridge the political gap between the local government and the local people. In other words, the implementation of this transfer policy functions as an effort to maintain a political communication between local governments with their people intensively [1]. Besides that, regional authority might also receive its right as the executor of regional administration and manager of culturalbased potentials. Some political scientists believe that decentralization would be a better way to increase public service as well as to rise local people's welfare as seen in many countries which have totally implemented this system [3]. Conceptually, fiscal decentralization shall be closely linked to the distribution of regional tax and revenue, funding obligation, and the autonomy of each level of sub-national government. In the meantime, Sidik (2002) believed that fiscal decentralization could empower the function of local assets that may be explored and utilized by local people [6].

\section{Methodology}

The research on this paper employs a constructivism approach with qualitative method. Fundamentally, constructivism points out that people construct their own understanding and knowledge of the world through experiencing things and reflecting on those experiences. This method employs several steps. The data was collected through several methods such as documentation research, in depth-interview and a Focus Group Discussion. Pekanbaru, Semarang, Batam, and Special Capital Region (DKI) Jakarta were chosen as research sites. 
Pekanbaru and Semarang were chosen due to their experiences as the cities with lowest growth of Rural and Urban Property Tax revenue. Balikpapan was also actually including into the city with lowest growth, but this city is excluding due to anomaly revenue from Land and Building Rights Transfer Duty and Rural and Urban Property Tax [9]. In the meantime, DKI Jakarta was also taken due to its position as capital city of Indonesia as well as Batam was selected as a city with complexity problem and become a pioneer in the implementation of Free Trade Zone in Indonesia.

\section{Results and discussions}

According to our comprehensive study, it is found some determinant variables that cause the difficulties on the transfer policy from central into regional government, namely (1) the weakness of bureaucratic attitude adhering to local government; (2) central and regional government are still not on the same page on fee collection of Rural and Urban Property Tax; (3) the unclear formulation on collection fee of Rural and Urban Property Tax; (4) the lack of competency of people in the local government and somewhat short of experiences in the area of Rural and Urban Property Tax. In order to help to mitigate the difficulties, several policy recommendations are proposed as follow:

\subsection{The need of bureaucratic reform for local government particularly for tax officials}

Before the implementation of Government Law 28/2010, almost all of the steps in the collections of Rural and Urban Property Tax are performed by tax officials in central government. The share of local government is limited only in the submission of Notice of Rural and Urban Property Tax Payable with the amount less than IDR500,000 as well as collection the Rural and Urban Property Tax revenue from tax payers. Unfortunately, deviations rise under this method indicated by the Notice of Tax Receipt and the reluctance of local authorities to install an online tax payment system. Therefore, a bureaucratic reform for the local government in general and for tax officials is necessary.

\subsection{The need to change the treatment toward a collection fee}

Under the implementation of Government Regulation 47/1985 on Share of Property Tax Revenue among Central and Local Government, the part for central and local was $10 \%$ and $90 \%$. Yet, the portion for local authority would be previously deducted by $10 \%$ of $90 \%$ as collection fee. Then, the net amount was distributed for province and district for each $20 \%$ and $80 \%$.

In 2000, a fundamental change occurred when Government Regulation 16/2000 enacted. Those changes covered the share for central and local was $10 \%$ and $81 \%$ and the rest of $9 \%$ as collection fee. Then, $10 \%$ belonged to central were distributed with share $6,5 \%$ for all districts in Indonesia in average, and 3,5\% for district when realization reach beyond the target as an incentive. Unfortunately, deviation occurred when local governments take as a loan from the bank to pay property tax as if the realization of property tax revenue achieved or even beyond the target. In turn, this unfair achievement got some incentives as bonus. 


\subsection{The need to reformulate the collection fee}

A couple of audit institutions either Financial Supreme Court (BPK) or Corruption Alleviation Commission (KPK) found many deviations on property tax collection fee. Hence, Financial Supreme Court asked central government to review all regulations on this subjects. Even Corruption Alleviation Commission found inconsistencies in some regulations concerning this collection fee, for instance a contradiction between Ministry of Domestic Affair Decree 35/2002 on Guidance of Allocation for Regional Tax Collection Fee and Government Regulation 65/2001 on Regional Tax.

\subsection{The need to strengthen the human resources}

In terms of providing the tax officials, central government has prepared a center of capacity building such as the existence of High School of State Accountancy. Furthermore, Directorate General of Tax has also provided any workshops and training that regularly performed to build a highly qualified people for handling Rural and Urban Property Tax as needed.

Regrettably, the existence of highly qualified people has not been utilized optimally due to political reasons, for instance a change of a chairman in regional government are occasionally followed with a change of tax officials. For this reason, there should have been a regulation stating a minimum period for a tax official working in a particular place at regional authorities. Regional government of Batam has been employing this standard.

A difficulty to provide competent and capable human resources could also be shown from the development of regional rules on Rural and Urban Property Tax. Until 2012, the existence of regional government with status of unwell-prepared of regulations on Rural and Urban Property Tax still huge, reaching 42,28\%. In order to help to solve the problem, central government developes a technical assistance for the area of regulation making process. A paradoxical occurs when the quality of local government tax official tend to decline, while the quantity is increased. Also, the trend of employee spending is improving steadily and continuously. The details of figures could be seen in the Table 2 [9].

Table 2. The Trend of Spending for Regional Authorities 2009-2012.

\begin{tabular}{|c|c|c|c|c|}
\hline $\begin{array}{c}\text { Type of Regional Expenditure } \\
\text { (in billion IDR) }\end{array}$ & $\mathbf{2 0 0 9}$ & $\mathbf{2 0 1 0}$ & $\mathbf{2 0 1 1}$ & $\mathbf{2 0 1 2}$ \\
\hline Employee Expenditure & 180.439 & 198.562 & 229.081 & 261.153 \\
\hline Goods and Service Expenditure & 79.6 & 82.007 & 104.221 & 122.225 \\
\hline Capital Expenditures & 114.598 & 96.179 & 113.523 & 137.438 \\
\hline Miscellaneous Expenditure & 40.594 & 50.11 & 48.449 & 71.071 \\
\hline
\end{tabular}

\section{Conclusions}

As the difficulties are remains and several regional governments shows the unprepared status, the transfer policy of Rural and Urban Property Tax from central into local government should continue. Moreover, this policy might not be terminated due to lack of Rural and Urban Property Tax revenues in a particular local authority. Although intergovernmental transfers and shared taxes typically dominate the financing framework, local own revenues, although perhaps small, are critically important to enhance local autonomy, governance accountability, ownership and responsibility while providing an 
important source of additional funding (at the margin) for local budgets [4]. Local government shall not have any anxiety with the prospect of declining Rural and Urban Property Tax revenue since central government has already prepared a mechanism to rebalance the intergovernmental inequality through the distribution of General Allocation Fund in the state budget. In addition, it should restructure the regional fiscal policies to fit with the transfer policy of Rural and Urban Property Tax. If properly designed, fiscal policies can be an effective tool for redressing social and economic inequality [7].

\section{References}

1. E. S. Irianto. (2012). An Empirical Study of Tax as an Instrument of Democratization. International Journal of Administrative Science \& Organization, 19(3), 162-174.

2. R. E. Jaweng, Robert Endi. Review the Policy of Decentralization and Regional Autonomy, Critical Reflection of Regional Autonomy (Jakarta, Regional Autonomy Monitoring Brief, 2012).

3. A. G. Karim, Abdul Gafar, Amirudin, M. Sukmajati, A. Nur. The Issue of Complexity of Local Autonomous in Indonesia (Yogyakarta, The Governmental Science Program, Faculty of Social and Political Science, Gadjah Mada University \& Pustaka Pelajar, 2003).

4. R. Kelly. Making the Property Tax Work. Chapter forthcoming in Taxation and Development: The Weakest Link - Essays in Honor of Roy Bahl, Working Paper 1311, Andrew Young School of Public Policy (2013).

5. A. Lutfi, Inayati, A. Hendrawan, H. Rosdiana. Land and Building Tax for Urban and Suburban Sectors Devolution: Challenges and Opportunity in Strengthening Taxing Capacity to Boost Regional Competitiveness (Depok, UI Press, 2013).

6. M. Sidik. Optimization Local Taxes and Charges to Strengthening Local Revenue Capacity. Paper presented at 21st Graduation Ceremony of Administrative Science College - National Institute of Public Administration Bandung, 10 April 2002.

7. F. Stewart, R. Venugopal. CRISE Policy Briefing No. 2: Inequality and Fiscal Policy (United Kingdom: Centre for Research on Inequality, Human Security and Ethnicity University of Oxford, 2009)

8. The Directorate General of Financial Balance of the Ministry of Finance of the Republic of Indonesia. Supplementary Handbook of Governance and Local Development in 2013: Affirmative Policy in Regional Development Acceleration for Increased Public Welfare (Jakarta, The Ministry of Finance of the Republic of Indonesia, 2013)

9. Data from Ministry of Finance of the Republic of Indonesia (2013). 